\title{
EKSISTENSI MANUSIA DALAM REPRESI PERADABAN MODERN (Studi Kritis Terhadap Pemikiran Herbert Marcuse)
}

Oleh :

Ai Rosmiati

Universitas Islam Negeri Sunan Gunung Djati Bandung

Email: Airos01@gmail.com

\begin{abstract}
Abstrak
Kemajuan teknologi seharusnya menjanjikan kemudahan-kemudahan bagi manusia. Sehingga manusia mempunyai waktu yang banyak untuk mendapatkan kebebasannya. Namun kenyataan itu hanya terlahir dalam mimpi. Ketika teknologi secara terang-terangan mengawinkan kekuasaannya dengan sistem politik, secara sah telah melahirkan penindasan yang tak terkendalikan terhadap kebebasan manusia. Manusia digiring masuk dalam dunia 'entah berantah' yang terjauh dari dunia eksistensinya, dan seketika menegaskan dirinya sebagai 'mayat-mayat' hidup yang harus berkerumun dalam sebuah sistem penindasan. Pada posisi ini, Herbert Marcuse sebagai seorang pemikir yang mencoba membedah problem eksistensi manusia dalam sebuah analisis yang lebih mendalam, memulai pembongkaran sistem penindasan ini dengan beranjak dari dunia alam bawah sadar manusia yang telah terepresi. Marcuse menempatkan problem represi manusia dalam kacamata yang berbeda. Marcuse melihat bahwa represi pada batasnya, dibutuhkan dalam menyokong terbentuknya sebuah peradaban yang sehat. Namun, ketika represi dipergunakan sebagai sebuah situasi yang melebih-lebihkan represi (surplus respesi) demi suatu kepentingan kelompok, maka akan menimbulkan sebuah penindasan manusia. Kenyataan tersebut, telah melahirkan sebuah ketertarikan yang mendalam terhadap pemikiran Herbert Marcuse dan menggiring penulis untuk melacak kembali problem eksistensi manusia dalam peradaban modern yang telah melahirkan sebuah sistem penindasan. Dalam analisisnya yang membedah persoalan represi manusia dengan beranjak dari alam bawah sadar manusia, Marcuse menyimpulkan bahwa manusia mampu membebaskan dirinya hanya melalui perubahan yang mendalam terhadap sifat represi teknologi dan industri modern, sehingga sifat represifnya tidak lagi memperbudak manusia. Terlepas dari karakter utopis yang terlihat dalam pemikirannya, secara umum pemikirannya telah memberikan analisis yang tajam yang bisa dibaca ulang sebagai dasar kerangka yang lebih kokoh dalam usaha mewujudkan pergerakan peradaban yang lebih baik.
\end{abstract}


Kata Kunci: Eksistensi manusia, pemikiran herbert Marcuse

\begin{abstract}
Advances in technology should promise convenience for humans. So that humans have a lot of time to get their freedom. But that reality was only born in a dream. When technology openly marries its power with the political system, it has legitimately produced an uncontrolled suppression of human freedom. Humans are herded into the world of "the unknown place" which is the furthest from the world of existence, and immediately assert themselves as "living corpses" that must be gathered in a system of oppression. In this position, Herbert Marcuse as a thinker who tried to dissect the problem of human existence in a more in-depth analysis, began to dismantle this system of oppression by moving from the repressed world of the human subconscious. Marcuse places the problem of human repression in a different perspective. Marcuse saw that repression at its limits was needed to support the formation of a healthy civilization. However, when repression is used as a situation that exaggerates repression (surplus response) for a group interest, it will cause a human oppression. This fact has given rise to a deep interest in Herbert Marcuse's thoughts and led the writer to trace back the problem of human existence in modern civilization which has given birth to a system of oppression. In his analysis of the issue of human repression by moving from the human subconscious, Marcuse concluded that humans were able to free themselves only through profound changes in the nature of technological repression and modern industry, so that their repressive nature no longer enslaved humans. Apart from the utopian character seen in his thinking, in general his thoughts have provided a sharp analysis that can be re-read as the basis of a more robust framework in an effort to realize a better civilization movement.
\end{abstract}

Keywords: Human existence, the thought of Herbert Marcuse

\title{
A. Pendahuluan
}

Keterasingan merupakan kondisi yang dialami oleh masyarakat modern. Kondisi alienasi ini terjadi karena manusia sampai pada titik di mana ia diperbudak oleh ciptaannya sendiri. Tentu saja ciptaan-ciptaan manusia ini hadir demi pemenuhan kebutuhan dan cita-cita dari manusia itu sendiri. ${ }^{1}$

\footnotetext{
${ }^{1}$ Erich Form, Masyarakat Yang Sehat, Yayasan Obor, Jakarta,1995, hlm. 136-137.
} 
Bambang Sugiharto menjelaskan beberapa ciri dan tanda dari konsekuensi manusia modern. Ciri tersebut ialah: pertama, pandangan dualistik, yang membelah kenyataan menjadi oposisi biner. Manifestasi dari pandangan ini bisa dilihat pada dikotomi relasi manusia dan alam, yang kemudian menyebabkan krisis ekologi, karena alam disubordinasi. Kedua, pandangan positivistik dan objektifistis, yang berimplikasi pada objektifikasi manusia. Dalam konteks sosial, masyarakat pada akhirnya dianggap sebagai mesin yang bisa direkayasa. Ketiga, disorientasi moral dan religius, yang akarnya bisa dideteksi dari penegasan ilmu positif-empiris sebagai patokan kebenaran tertinggi. ${ }^{2}$

Konsekuensi yang keempat materialisme, yang kemudian menjadi pola perilaku dominan, di mana kenyataan material dianggap sebagai dasar dan akhir dari segala sesuatu. Kelima, militerisme. Militerisme ini hadir sebagai konsekuensi dari runtuhnya tatanan etiko-religius, yang membuat kekuasaan dijadikan sebagai dasar kontrol dan kendali atas manusia. Konsekuensi keenam ialah tribalisme. ${ }^{3}$

Heidegger melihat kenyataan ini lebih disebabkan oleh keberadaan manusia yang begitu kerasan bermukim di dalam dunia alat-alat sehingga tidak menyadari lagi ketergantungan kepada teknik. Dalam modernitas ketergantungan ini sudah menentukan ada kita sebagai bingkai (gestell), sehingga konflik dalam masyarakat modern tidak lagi disebabkan oleh kebencian, agresi ataupun pertentangan kelas, melainkan oleh anggapan bahwa menjadi manusia dewasa berarti mengukur, menundukan, dan mengekploitasi alam lewat alat-alat. Alat-alat ini dianggap sebagai ekstensi dari tubuh manusia. Dan dari posisi ini semuanya dipandang dari titik tolak tersebut. ${ }^{4}$

Alienasi dan ketakberumahan manusia di dunia modern merupakan kondisi yang membuat Homo Sapiens dipermiskin menjadi Homo Brutalis dalam rezim-rezim totaliter. Pengangguran dan pengungsian mencabut

${ }^{2}$ I Bambang Sugiharto, Op Cit, hlm. 29.

${ }^{3}$ Ibid, hlm. 29-30.

${ }^{4}$ F. Budi Hardiman, Heidegger dan Mistik Keseharian'Suatu Pengantar Menuju Sein Und Zeit', Cet-I, Gramedia, Jakarta, September 2003, hlm. 57. 
manusia dari dunia sosialnya, sehingga dalam keterlantaran itu manusia dihadapkan langsung pada situasi survival-nya yang saling mengancam. ${ }^{5}$ Manusia juga bisa tercerabut dari dunia dan dibuat tidak mampu saling bersentuhan. Itulah yang kemudian menjadikan manusia hanya sekedar kerumunan pengungsi atau massa yang dimobilisasi, yang berdesak-desakan namun tak pernah bersentuhan dalam suatu dunia bersama. Metropolis juga mampu menanduskan dunia yang dimukimi dan mengosongkannya dari makna, sehingga menjadi sekedar ruang kosong-makna, tempat orang selalu merasa asing didalamnya. ${ }^{6}$

Berkat perkembangan teknologi informasi, ruang batas antara mitos atau ada dengan dunia citraan, di mana manusia hidup dalam ruang tersebut. Bagi Heidegger, kembali kepada ada diartikan sebagai terlepasnya manusia dari perangkap paham humanisme rasional modern. Manusia tak bisa lagi diposisikan sebagai ukuran segala sesuatu dan landasan dalam menentukan bentuk kehidupannya di dunia, yang tanpa toleransi sama sekali terhadap perbedaan, yang tidak mengacuhkan kecenderungan pluralisme. $^{7}$

Istilah ada yang digunakan oleh Heidegger dalam melukiskan eksistensi yang bersifat praeksistensi manusia. Dengan pengertian, bahwa manusia hanya ada disebabkan oleh "ada" yang mendiami mendahuluinya, yang bukan ciptaan manusia sendiri. Umat manusia selalu menemukan dirinya telah terlempar atau tercetak di dalam satu posisi dalam rentang sejarah yang bukan hasil karyanya sendiri di satu tempat atau waktu tertentu. Humanisme harus memberikan homo humanus untuk menafsirkan tafsiran kehidupan (dalam ruang dan waktu) manusia sendiri di dalam $a d a{ }^{8}$

Pada sisi lain, manusia selalu larut dalam keseharian sehingga lupa akan ada-nya. Heidegger menyebut cara berada Dasein yang hadir dalam

\footnotetext{
${ }^{5}$ Ibid, hlm. 54.

${ }^{6} \mathrm{Ibid}$, hlm. 54. (Lihat pemikiran Hanah Arendt, dalam Elemente Und Usprunge totaler Herrschaft, tentang ulasan kemenduniaan Dasein pada arah yang berlawanan, yang diulas kemudian dalam buku F Budi Hardiman).

${ }^{7}$ Yasraf Amir Pilialang, Op Cit, hlm. 85 dan 83.

${ }^{8}$ Ibid, hlm. 82.
} 
keseharian ini sebagai das man, kata interpersonal yang merujuk pada orang. 'Kebersamaan' bagi Heidegger, telah melarutkan kenyataan khas yang didasarkan pada prinsip perbedaan, kemudian perbedaan ini menjadi hilang. Tepat pada titik itulah das man mewujudkan kediktatorannya. Manusia di satu pihak dia memang ingin mengenal ada-nya, tetapi lain pihak dia juga harus selalu berkubang di dalam keseharian yang mengasingkannya dari Ada-nya. ${ }^{9}$

Herbert Marcuse meyakini bahwa, one dimensional man (manusia dimensi satu) telah menjadi karakter dari masyarakat modern yang berbasis pada industri budaya yang massif. Industry ini telah menlenyapkan dimensi progresif dari seni klasik. Msyarakat seperti ini tetaplah bersifat irasional sebagai suatu keutuhan. Produktivitasnya begitu destruktif bagi pertumbuhkembangan yang bebas akan kebutuhan dan kemampuan umat manusia, kedamaian terpelihara berkat suatu ancaman akan terjadinya perang yang terus menerus, perkembangannya tergantung pada represi atas kemungkinan-kemungkinan nyata demi meredakan perjuangan bagi adanya eksistensi individu, nasional, dan internasional. ${ }^{10}$

Prinsip realitas pada batasnya, telah menindas dorongan-dorongan instingtual (prinsip kesenangan) manusia. Sigmund Freud menegaskan, bahwa produktivitas perdaban itu terbentuk melalui libido yang direpresi. Akan tetapi, perlu diketahui bahwa prinsip Freudisme ini bersifat ahistoris, sedangkan Marcuse meyakini bahwa represi tidak datang dari alam, tetapi dari manusia, dalam latar sejarah yang tampak. Di sini Marcuse memberi dimensi historis, sebuah proses dialektika yang tak henti-hentinya. Keterbelakangan historis, dapat menjadi peluang historis untuk membalikan putaran roda kemajuan menuju arah yang lain.

Berbeda dari pemikiran Erich Form yang mengurangi konfrontasi penindasan sosial dan keinginan dasar sebagai upaya menghilangkan penindasan penekanan represi. Marcuse melihat, bahwa represi dibutuhkan sebagai alat mepertahankan ras manusia. Dan kekangan merupakan

${ }^{9}$ F. Budi Hardiman, Op Cit, hlm. 62.

${ }^{10}$ Lihat Pendahuluan Herbert Marcuse, Manusia Satu Dimensi, terj. Silvester G, Syukur dan Yusup Priyasudiarja, Yayasan Bentang Budaya, Yogyakarta, Desember 2000, Cet-I, hlm. XVi. 
prasyarat bagi kemajuan. Namun, ketika represi dipergunakan sebagai sebuah kondisi surplus represi untuk kebutuhan/kepentingan kelompok, maka akan menimbulkan sebuah penindasan manusia.

\section{B. Hasil dan Pembahan}

\section{Represi Peradaban dalam Membentuk Manusia Satu Dimensi}

Konsep manusia satu dimensi dalam pandangan Marcuse berangkat dari asumsinya tentang masyarakat modern yang telah di dominasi oleh teknologi menjadi masyarakat teknokratis. Dalam melihat ketimpangan manusia modern saat ini, Marcuse memulainya dengan menganalisa sikap bawah sadar manusia yang akan membentuk manusia dalam satu dimensi. Sikap Marcuse dalam usaha penggabungan psikoanalisa Sigmund Frued dengan filsafat ekonomi Marx, dipicu oleh suatu ketidakpuasan yang terus memuncak terhadap Marxisme bahkan dalam bentuk penjelasan Hegelian dan mendorongnya untuk menelaah sejumlah hambatan psikologi dalam proses menuju perubahan sosial yang berarti.

Marcuse menawarkan untuk menggabungkan Freudisme dengan analisa kritis Marxisme. Dengan alasan bahwa perubahan radikal itu mungkin terjadi via dekonstruksi psikis, terkhusus ketika proletariat tak bisa diharapkan menjadi agen perubahan. Dalam upayanya tersebut, Marcuse mencoba mengungkap elemen-elemen di dalam psikoanalisis dan tidak memandang keluar dari sistem yang ada. Marcuse memulai analisanya dengan sebuah tesis awal tentang peradaban manusia. Di mana dia menggambarkan bahwa peradaban modern yang pada dasarnya di bangun di atas pengekangan eksistensi manusia, baik eksistensi sosial maupun eksistensi biologisnya:

“....Sejarah manusia adalah sejarah penindasan manusia. Kebudayaan mengekang tidak hanya eksistensi sosial manusia tetapi juga eksistensi biologisnya, tidak hanya bagian-bagian manusiawinya saja tetapi juga struktur instingtifnya." 11

${ }^{11}$ Herbert Marcuse, Cinta dan Peradaban, terj. Imam Baehaqie, Cet.I, Pusata Pelajar, Yogyakarta. hlm.11. 
Marcuse melihat bahwa peradaban manusia dibentuk dalam sebuah struktur penindasan eksistensi sosial manusia dan eksistensi psikisnya. Marcuse menganalisa problematika manusia modern dengan berpangkal pada kenyataan psikis manusia dalam membentuk peradaban represif yang semakin rasional pada zaman sekarang ini. Kenyataan ini tidak lepas dari fakta bahwa manusia modern merupakan masyarakat yang tidak sehat yang secara sadar ikut serta dalam upaya melanggengkan sistem penindasan.

Pada dasarnya, perubahan-perubahan aparatus insting manusia dipengaruhi oleh perubahan-perubahan aparatus mental dalam pergerakan peradaban, sehingga dorongan-dorongan kebinatangan secara tidak langsung berubah menjadi insting manusia karena pengaruh realitas eksternal yang mempengaruhinya. Realitas yang membentuk insting merupakan realitas dunia sosio historis yang memenuhi kebutuhankebutuhan insting tersebut. Dan peradaban dimulai ketika tujuan primer insting dalam upaya memenuhi kebutuhannya dibelokan secara efektif sehingga eksistensi psikis manusia dikekang dalam sebuah peradaban yang represif .

Relasi antara kebutuhan insting manusia dengan realitas sosio historis ditampilkan dalam dua kecenderungan mental manusia, yaitu dorongan id: libido plus thanatos dengan prinsip realitas (ego). Kedua konsep ini berkaitan dengan perbedaan antara proses sadar dan proses tak sadar yang ditandai dengan dua proses dan prinsip mental yang berbeda. Perbedaan kedua dimensi tersebut diperlihatkkan dalam sifat genetikhistoris yang membangunnya, dan dalam perbedaan stukturalnya. Perbedaan struktur ini terlihat dalam stuktur prinsip kesenangan yang meruakan stuktur alam tak sadar, sedangkan prinsip realitas dipengaruhi oleh dorongan dari luar.

Marcuse menjabarkan bahwa prinsip kesenangan merupakan sebuah proses mental yang lebih tua dan primer. Prinsip kesenangan di lihat sebagai satu-satunya proses mental yamg tersisa sebelum tranformasi dari struktur prinsif kesenangan menjadi prinsip realitas. ${ }^{12}$ Transformasi mental antara prinsip kesenangan yang mulai masuk dalam stuktur prinsip

\footnotetext{
${ }^{12}$ Ibid, hlm. 13.
} 
realitas merupakan sebuah proses memenuhi kebutuhan akan id kesenanggan dan berupaya menghindari tindakan-tindakan yang dapat menghasilkan ketidaksenangan dalam kemunduran aktivitas mental tersebut. Prinsip kesenangan yang tidak terkendali akan mengalami konflik dengan lingkungan alamiah dan lingkungan manusia karena tidak terpenuhinya kebutuhan pemenuhan id kesenangan oleh prinsip realitas. Pengalaman traumatis, akibat individu yang sadar tentang kemustahilan pemenuhan hasrat penuh serta tanpa rasa sakit dalam realitas, pun muncul. Kemudian prinsip realitas mengambil alih peran mental sebagai satusatunya prinsip yang mampu mengendalikan manusia.

Momen kekalahan prinsip kesenangan oleh prinsif realitas menjadi awal terbentuknya kontrol-kontrol diterapkan pada manusia, sehingga manusia mulai belajar menanggalkan kesenangan yang destruktif dan menggantikannya dengan kesanangan yang ditunda dan dikendalikan. Pencapaian ini diperoleh melalui pengingkaran dan pengendalian prinsip kesenangan melalui prinsip realitas. Marcuse melihat bahwa prinsip realitas tidak hanya mendorong perubahan dalam bentuk dan penetapan waktu kesenangan tetapi juga dalam substansi kesenangan itu sendiri. Penundukan dan pengalihan pemuasan instingtif yang destruktif kepada norma dan hubungan sosial yang ada, menjadi indicator dari penyesuaian prinsip realitas dengan prinsip kesenangan. Prinsip realiatas pada akhirnya mengubah isi kesenangan yang destruktif menjadi kesenangan yang dikendalikan.

Marcuse meyakini bahwa prinsip realitas pada awalnya ingin mengembangkan fungsi akal budi manusia dalam upaya menguji realitas ${ }^{13}$ belajar membuat distingsi benar-salah, baik-jahat, dll yang tak mampu dilakukan oleh prinsip kesenangan. Prinsip realitas mengajarkan manusia untuk menjadi subjek yang sadar, yang mampu berpikir sehat dan segala tindakannya digerakan oleh rasionalitas. Namun, pada perkembangan selanjutnya, ketika prinsip realitas berubah menjadi lembaga-lembaga, dan perkumpulan kelompok-kelompok merubahnya menjadi sistem norma-

\footnotetext{
${ }^{13}$ Ibid, hlm.15.
} 
norma , kesadaran yang di bangun berubah menjadi lebih progresif dalam mengekang kesadaran manusia.

"Penggantian prinsip kesenangan dengan prinsip realitas menjadi sebuah peristiwa traumatis yang hebat dalam perkembangan manusia perkembangan genus (filogenesis) maupun perkembangan individual (ontogenesis)............ secara filogenesis, peristiwa ini terjadi untuk pertama kali dalam kelompok besar purba, ketika bapa purba memonopoli kekuasaan dan kesenangan serta memaksa sang anak mengingkari hasrathasratnya. Secara ontogenetis peristiwa ini terjadi selama priode kanakkanak awal dan ketundukan pada prinsip realitas ini diperkuat oleh orang tua dan para pendidik lain. Tetapi, baik pada level umum maupun individual, kepatuhan ini terus-menerus diciptakan. Peraturan bapa purba dilanjutkan, setelah pemberontakan yang pertama, dengan peraturan sang anak, dan klan saudara berkembang menjadi dominasi dominasi yang terlembagakan secara sosial dan politis." ${ }^{14}$

Prinsip realitas yang telah berubah dalam bentuk sistem lembagalembaga menegaskan keberadaannya dalam sebuah aturan-aturan yang menjadi syarat sistem-siatem institusi. Sehingga individu yang tumbuh dan berkembang dalam sistem tersebut, mempelajari syarat-syarat prinsip realitas sebagai hukum dan peraturan, yang kemudian mewariskan syarat-syarat prinsip realitas pada generasi selanjutnya. Pada posisi lain, kemenangan prinsip realitas atas prinsip kesenangan selalu melahirkan ketakutan terhadap prinsip kesenangan yang mencoba membebaskan diri dari sistem prinsip realitas. Sehingga prinsifprealitas pada perkembangannya, akan terus menerus membangun kembali sistemnya, sebagai upaya membendung prinsip kesenangan yang selalu ingin membebaskan diri dalam upaya memenuhi kebutuhan-kebutuhan terhadap id kesenangannya.

“.......perjuangan purba untuk bertahan hidup ini adalah perjuangan yang 'abadi' dan oleh karena itu prinsip realitas dan prinsip kesenangan memang selamanya 'antagonistik' bertentangan. Gagasan bahwa suatu peradaban yang non-represif adalah suatu ketidakmungkinan." ${ }^{15}$

\footnotetext{
${ }^{14}$ Ibid, hlm. 16 .

${ }^{15}$ Ibid, hlm.19.
} 
Pada posisi ini, terlihat bahwa prinsip realitas selalu diidentikan dengan sebuah gerak represif terhadap eksistensi manusia yang mengekang dan membelokan insting kesenangan manusia. Namun, Marcuse melihat bahwa represi pada batasnya diperlukan sebagai alat kontrol terhadap id kesenangan manusia yang tidak mengenal waktu dan ruang. Marcuse menjabarkan bahwa prinsip kesenangan tidak bisa dibiarkan bebas dan memenuhi seluruh kebutuhan-kebutuhannya. Mereka harus dikendalikan dan disublimasikan menjadi kerja kesadaran yang akan membangun sebuah manusia yang mampu mengendalikan eksistensinya dalam realitas. Marcuse membedakan represi dalam dua pengertian, pertama represi sebagai arti dasar dan represi surplus sebagai bentuk pembatasan-pembatasan yang disyaratkan oleh dominasi sosial.

Marcuse meliahat bahwa, represi dalam artian dasar dimaknai sebagai sebuah kontrol yang dibutuhkan sehingga prinsip realitas mendapatkan bentuknya dalam sebuah gerakan peradaban yang non-represif dan menjadi syarat yang diperlukan dalam upaya pelestarian eksistensi manusia dalam peradaban. Kontrol-kontrol ini dibentuk dalam sebuah hukum-hukum dan nilai-nilai yang menularkan dan mendorong modifikasi insting yang dibutuhkan oleh sistem tersebut sehingga insting kesenangan manusia dapat bermanfaat dalam membangun peradaban manusia.

Marcuse melihat bahwa prinsip realitas pada dasarnya selalu menuntut adanya kontrol represif dalam derajat dan ruang lingkup tertentu. Namun ketika lembaga-lembaga dalam prinsip realitas yang historis dan memilki kepentingan-kepentingan dominasi yang lebih spesifik membutuhkan sebuah pengendalian yang lebih besar terhadap manusia, akhirnya lembaga-lembaga tersebut memper-kenalkan sebuah kontrolkontrol tambahan dalam upaya mepersatukan kepentingan-kepentingan yang berbeda. Kontrol tambahan ini disebut sebagai represi yang berlebihan atau represi surplus. ${ }^{16}$ Represi surplus pada titik ini, diartikan sebagai sebuah pengendalian yang berlebihan terhadap prinsip kesenangan, sehingga prinsip kesenangan manusia tidak hanya dialihkan tetapi dihilangkan

\footnotetext{
${ }^{16}$ Ibid. hlm. 44.
} 
dalam sebuah kontrol-kontrol yang yang ketat. Represi surplus akan melahirkan alienasi dan ketertindasan eksistensi manusia.

Bentuk-bentuk represi merupakan konsekuensi dari lahirnya proses mental dalam prinsip realitas. Marcuse membagi kecenderungan yang menjadi sebab lahirnya dominasi terhadap manusia dalam prinsip realitas dalam dua bentuk, pertama kelangkaan (lebensnot, Ananke) dan prinsip prestasi sebagai upaya merasionalkan penindasan. Kelangkaan dalam proses pengatasiannya berubah menjadi sistem dominasi dalam prinsip realitas. Kelangkaan (lebensnot, Ananke) lahir dalam sebuah perjuangan demi kelangsungan hidup dalam upaya memuaskan kebutuhan-kebutuhan manusia tanpa adanya kontrol, pengingkaran, dan penundaan yang konstan. Setiap kekuasan dalam mengatasi kelangkaan akan selalu mensyaratkan kerja, sebagai usaha untuk mendapatkan sarana-sarana pemuas kebutuhan tersebut.

Kelangkaan (lebensnot, Ananke) mengajarkan kepada manusia bahwa manusia tidak dapat memuaskan dorongan instingtif mereka dengan bebas dan tidak dapat hidup mengikuti prinsip kesenangan. ${ }^{17}$ Manusia didorong untuk mengatasi kelangkaan dengan mensublimasikan insting kesenangan menjadi aktivitas kerja. Kelangkaan dalam prinsip realitas akan selalu menuntut penggorganisasian dan pengaturan yang spesifik dalam mengatur setiap kebutuhan manusia yang terus berkembang. Distribusi kelangkaan dan upaya pengatasannya dibentuk melalui sebuh aktivitas kerja yang dipaksakan terhadap individu melalui kendali-kendali yang mengekang eksistensi manusia. Kendali-kendali ini dilakukan oleh individu atau kelompok yang berkuasa dalam aktivitas melesatarikan dan memajukan tujuan-tujuan pribadinya sebagai upaya mengatasi kelangkaan. ${ }^{18}$

Sistem kendali yang digunakan dalam mengatasi kelangkaan kemudian diintensifkan menjadi sebuah prinsip prestasi yang mensyaratkan dominasi terhadap anggota-anggotanya. ${ }^{19}$ Dominasi ini dibentuk dalam sebuah stratifikasi sosial yang ditentukan sesuai dengan kebutuhan institusi

\footnotetext{
${ }^{17}$ Ibid. hlm.18

${ }^{18}$ Ibid, hlm 43.

${ }^{19}$ Ibid, hlm.53.
} 
melalui persaingan. Sehingga manusia diorganisir dan dikelompokkan sesuai dengan kemampuan-kemampuan kompetitif mereka. Manusia dituntut untuk mematuhi aturan-aturan yang ditentukan dalam aktivitas kerja sebagai sarana pemenuhan kepentingan-dominasi dari institusi. Manusia dipaksa untuk tunduk terhadap dominasi apabila masih ingin bertahan hidup.

“....pembatasan-pembatasan yang dipaksakan bekerja pada individu sebagai hukum-hukum objektif eksternal dan sebagai kekuatan yang diinternalisasikan: otoritas sosial diserap kedalam kesadaran dan ketidaksadaran individu dan bekerja sebagai keinginan, moralitas, dan pemenuhan kebutuhan individu sendiri. Dalam perkembangan yang normal, individu menghidupi penindasannya dengan bebas sebagai hidupnya sendiri: ia menginginkan apa yang mesti ia inginkan; pemuasan kebutuhannya tidak hanya menguntungkan bagi dirinya sendiri tetapi juga orang lain......."

Marcuse menggambarkan prinsip prestasi sebagai prinsip masyarakat antagonis dan serakah. ${ }^{21}$ Dalam prinsip ini, manusia dihadapkan dengan kenyataan bahwa kerja mereka merupakan kerja yang dilakukan untuk suatu aparatus yang tidak mereka kontrol. Dan kerja manusia merupakan sebuah ketaatan terhadap dominasi yang ditetapkan dari luar dirinya (realitas) sehingga manusia melakukan aktivitas kerja sebagai usaha memajukan dan melanggengkan sistem dominasi tersebut. Manusia bekerja tidak hanya dalam upaya memenuhi kebutuhanannya sejatinya namun atas dorongan aturan-aturan yang mengharuskan manusia untuk tetap bekerja. Aktivitas kerja pada posisi ini, tidak lagi sebagai suatu bentuk eksistensi manusia namun berubah menjadi sistem alienasi yang semakin dirasionalkan. Sehingga dominasi yang dijalankan dalam prinsip prestasi berubah bentuk menjadi sebuah kewajaran yang dapat diterima dengan baik.

“....energi instingtif yang dikekang ini tidak menumpuk dalam instinginsting agresif (yang tidak tersublimasikan) karena penggunaan sosialnya

\footnotetext{
${ }^{20} \mathrm{Ibid}, \mathrm{hlm} .55$.

${ }^{21}$ Ibid, hlm. 53.
} 
(dalam kerja) memelihara dan bahkan memperkaya hidup manusia. Pembatasan-pembatasan atas libido nampak semakin rasional ketika pembatasan-pembatasan tersebut semakin universal, semakin merasuki keseluruh masyarakat."22

Prinsip prestasi mengatur tubuh dan pikiran menjadi instrumentinstrument kerja yang teralienasi. Manusia bekerja tidak lagi sesuai dengan kemampuan kecerdasannya, namun bekerja pada sebuah hukum-hukum alienasi yang diuniversalkan. Manusia hanya eksis paruh waktu, selama jam kerja, ia hanya instrumen aktivitas-aktivitas yang teralienasi dan sisanya adalah saat di mana manusia bisa menjadi manusia yang bebas bagi dirinya sendiri sebagai waktu potensial untuk mencukupi kesenangan. Namun pada kenyataannya waktu senggang yang tersisa tidak mampu mencukupi insting kesenangan yang tidak mengenal waktu. ${ }^{23}$

".......waktu kerja yang merupakan waktu yang paling banyak menyita hidup individu, adalah waktu yang menyakitkan. Bagi pekerja yang teralienasi, waktu ini adalah waktu dimana tidak ada pemuasan, pemenuhan kebutuhan individu, negasi dari prinsip kesenangan." ${ }^{24}$

Kontrol atas waktu senggang diciptakan oleh rentang jam kerja. Di mana, waktu senggang yang dimiliki oleh setiap manusia ditujukan sebagai tujuan mereproduksi tenaga agar bisa kembali bekerja. Bentuk represif terhadap waktu senggang, pada sebuah peradaban yang mutakhir, kemudian dikembangkan oleh industri-industri hiburan. Bentuk kontrol ini, terlihat dengan semakin maraknya industri-industri hiburan yang menyuguhkan pemenuhan insting kesenangan pada waktu tepat bebas

${ }^{22}$ Ibid, hlm. 54-55.

${ }^{23}$ Perbandingan ini bisa terlihat dalam sebuah estimasi waktu, 'apabila rata-rata jam kerja, termasuk persiapan, dan perjalanan menuju dan dari kerja, total seluruhnya sepuluh jam. Dibandingkan dengan kebutuhan-apabila-kebutuhan biologis untuk tidur dan tiga kali makan membutuhkan waktu sepuluh jam lagi. maka waktu bebas yang dimiliki setiap individu hanya empat jam, diaman dua puluh jam digunakan dalam aktivitas kerja dan sisanya empat jam sebagai waktu senggang yang dapat digunakan untuk mendapatkan kesenangan. Lihat Penjabaran Marcuse tentang waktu bebas manusia, Ibid, hlm. 56.

${ }^{24}$ Ibid, hlm. 54. 
individu di mulai dan kemudian dihentikan pada saat aktivitas kerja kembali berlangsung. Semakin diintensifkannya kontol-kontrol terhadap insting kesenangan membuktikan bahwa prinsip realitas, pada dasarnya, takut akan pemberontakan dalam waktu-waktu senggang yang dilakukan oleh manusia. Sehingga bentuk-bentuk kontrol terhadap kebebasan eksistensi manusia dilakukan selama dua puluh empat jam.

"individu tidak ditinggal sendirian, karena apabila ditinggal sendirian, dan berhadapan dengan diri sendiri, serta didukung oleh kecerdasan yang bebas yang sadar akan potensi-potensi pembebasan dari represi, penindasan realitas, energi libido yang dihidupkan oleh id, akan menghantam pembatasan-pembatasan yang berasal yang berasal dari luar dan berjuang demi pembebasan bidang-bidang hubungan eksistensial yang lebih besar, dan oleh karena itu akan menghancurkan ego realitas dan penindasan-penindasannya." 25

Penindasan atas manusia hampir total. Manusia tidak lagi mempunyai waktu bebas tanpa sebuah kontrol. Sehingga seluruh aktivitas dalam mekanika cara penyusunan mesin, rutinitas kantoran, ritual jual beli, dan industri hiburan telah bebas dari potensi-potensi eksistensi manusia. Hubungan kerja sebagian besar telah menjadi hubungan antarindividu sebagai objek manajemen ilmiah dan sebagai ahli-ahli efisiensi yang dapat dipertukarkan. Kompetitif yang menjadi ciri utama prinsip prestasi, pada dasarnya membutuhkan individualitas dan spontanitas dalam derajat tertentu sebagai sebuah aktivitas persaingan yang terus menerus. Sehingga kecurigaan akan yang lain semakin meningkat dan menimbulkan keinginan untuk dapat mendominasi manusia lainnya. Manusia dirubah menjadi sekumpulan yang terus berperang untuk mengukuhkan kekuasaannya dalam sebuah sistem perasaingan, sehingga tercerabut dari dunia eksistensinya.

Di balik permukaan peradaban yang ilusif, keseluruhan dunia kerja dan penciptaannya telah menjadi sebuah sistem benda-benda hidup dan benda-benda mati. Semuanya dipandang hanya sebagai subjek administrasi.

\footnotetext{
${ }^{25}$ Ibid, hlm. 57.
} 
Eksistensi manusia dirubah menjadi bahan-bahan, materi, material yang tidak mempunyai prinsip gerakan dalam dirinya sendiri. Kesadaran yang semakin dikurangi bebannya dari otonomi, direduksi pada tugas-tugas mengatur koordinasi individu dan keseluruhan. Dan kesadaran individu atas represi yang dominan dibutakan oleh pembatasan-pembatasan yang dimanipulasi atas alam sadar manusia dan mengubah isi kebahagiaan yang sebenarnya menjadi kesenangan-kesenangan dalam bentuk baru yang diciptakan sebagai bentuk dominasi.

Marcuse menganalisa bahwa dengan menurunnya alam sadar manusia karena penyerapan eksistensi manusia dalam komunikasi masa dan oleh pembatasan terhadap pengetahuan realitas dari luar, telah mengakibatkan manusia tidak benar-benar paham terhadap realitas yang sebenarnya. Kekuatan mesin, dan hiburan populer telah mempersatukan manusia kedalam keadaan kesenangan yang jauh dari rasa sakit dan ketidaksenangan. Gagasan-gagasan penindasan yang sebenarnya, tentang eksistensi manusia yang dipenjara dalam kontrol kerja dihilangkan dari kesadaran bawah sadar manusia sehingga yang lahir hanya kesadaran palsu tentang dunia kerja sebagai bentuk kebahagiaan yang nyata baginya.

"Proses ini mengubah isi kebahagiaan. ....kebahagian bukan hanya dalam sekedar perasaan kepuasan melainkan dalam realitas kebebasan dan kepuasan kebahagian mensyaratkan pengetahuan: kebahagiaan adalah hak prerogatif animale rationale. ......dan karena pengetahuan yang dianggap benar oleh seluruh masyarakat tidak, atau lebih tepatnya sulit, menjadi kondusif bagi kebahagiaan, keadaan tanpa rasa sakit, keadaan ini sudah cukup membuat bahagia individu. ${ }^{26}$

Marcuse beranggapan bahwa dengan realitas masyarakat modern seperti ini, kebahagian dirubah maknanya menjadi sebuah kebahagian palsu dan semu. Dan kecemasan yang dianggap sebagai kondisi eksistensial manusia, ${ }^{27}$ telah digantikan dengan bentuk kebahagian-kebahagian yang ditawarkan oleh peradaban. Kecemasan dihilangkan dengan kebahagiaan dan kepuasaan yang didapat dalam dunia kerja, melalui pemaksimalan

\footnotetext{
${ }^{26} \mathrm{Ibid}, \mathrm{hlm} .131$.

${ }^{27} \mathrm{Ibid}, \mathrm{hlm} .131$.
} 
mesin yang semakin dirasionalkan, hiburan yang menyenangkan, dan aktivitas yang jauh dari rasa sakit. Pada akhirnya, kecemasan dibalikan maknanya, menjadi ketakutan manusia akan terbebasnya dari sistem dominasi tersebut. Sehingga manusia semakin mengidentikan eksistensi dirinya dengan laju peradaban yang represif.

“.....bisa memaksakan melemahnya posisi negatif kelas-kelas pekerja; kelaskelas ini tidak lagi tampak menjadi kontradiksi yang pada masyarakat yang sudah mapan. ........berwujud dalam hal eksploitasi lenyap dibelakang penampilan rasionalitas objektif. Kebencian dan frustasi berasal dari target spesifik mereka, dan selubung teknologi menyembunyikan reproduksi kepincangan dan perbudakan. Dengan kemajuan teknis sebagai instrumen, ketidakbebasan dalam pengertian penguasaan manusia akan peralatan-peralatan produktifnya diteruskan dan diintensifkan didalam bentuk-bentuk kebebasan dan kenyamanan yang beraneka ragam. Ciri-ciri yang baru yaitu adanya rasionalitas yang kuat sekali di dalam perusahaanperusahaan yang irasional ini, dan adanya kedalaman prakondisi yang membentuk gerakan-gerakan dan aspirasi-aspirasi naluriah dari individuindividu dan menyembunyikan perbedaan antara kesadaran yang sejati dan kesadaran yang palsu." 28

Kelahiran teknologi dan maraknya hiburan populer telah membentuk sebuah kesenangan ilusif dan mendorong manusia untuk melupakan antara kesadaran sejati dan kesadaran palsu. Antara kesadaran untuk mencapai kebebasannya dalam memenuhi insting kesenangan yang sebenarnya dengan kesenangan yang diciptakan sebagai bentuk lain dari kontrol peradaban. Kebebasan berpikir, oposisi politis dan otonomi, kehilangan fungsi kritisnya karena dicerabut.

"jangkauan kepuasan yang secara sosial dimungkinkan dan diinginkan diperluas secara besar, tetapi melalui kepuasan ini, Prinsip Kesenangan direduksi dirampas klaim-klaimnya yang tidak bisa direkonsiliasikan dengan masyarakat yang sudah mapan. Kesenangan, yang disesuaikan secara demikian, menghasilkan penyerahan." ${ }^{29}$

28 Herbert Marcuse, Manusia Satu Dimensi, Cet-1, Yayasan Bentang Budaya, Yogyakarta, hlm.47-49.

${ }^{29} \mathrm{Ibid}, \mathrm{hlm} .111$. 
Prinsip realitas menyerap budaya luhur sebagai sebuah hiasan dan bentuk pengendalian pasar. Insting kesenangan yang pada budaya luhur mensyaratkan sebuah kebebasan, nilai estetik, dan pemberontakan yang tinggi dirubah maknanya menjadi erostisisasi terhadap seksualitas. Sehingga dunia penghayatan dan ranah kebebasannya hilang dan berubah menjadi alat memajuakan peradaban industri. Kebebasan seksualitas yang menjadi ciri utama prinsip kesenangan dirubah maknanya menjadi sebuah nilai pasar (market value). Pada posisi ini, tubuh tidak hanya dirubah menjadi instrumen kerja tetapi tubuh dimungkinkan untuk menunjukan ciri-ciri seksualnya dalam dunia kerja sehari-hari dan dalam relasi-relasi kerjanya dengan masyarakat.

"para office girl dan sales girl yang seksi, eksekutif muda dan pengawas toko (floorwalker) yang tampan dan gagah merupakan komoditas yang sangat laris,...... toko-toko dan kantor-kantor membuka dirinya melalui jendelajendela kaca yang besar dan memperlihatkan para pegawainya; di dalamnya, bisa dilihat couter-counter yang tinggi dan partisi-partisi yang transparan." 30

Budaya luhur yang mencerminkan insting kesenangan dalam mencapai kebebasannya bangkit kembali setelah sebelumnya diambil alih oleh prinsip realitas sebagai sesuatu yang lain dari diri mereka, yang dikendalikan oleh prinsip realitas untuk mencapai sebuah kepenuhan dalam dominasi. Budaya luhur telah kehilangan hakekat dan kebenarannya sebagai bentuk ungkapan ketidak-bahagiaan dari kesadaran manusia terhadap dunianya. Garis pembatas antara seni dan kenyataan hidup seharihari dihilangkan dan ditutup menjadi sekedar barang dagangan yang di produksi dalam jumlah besar sebagai bentuk kesenangan baru yang diciptakan.

"sekarang jarak itu telah dihilangkan dan bersamanya juga dihilangkan pelanggaran dan tuduhan. Teks dan nadanya masih ada, tetapi jaraknya telah diatasi yang membuatnya Luft von anderen Planeten. Alienasi

\footnotetext{
${ }^{30} \mathrm{Ibid}, \mathrm{hlm} .111$.
} 
artistik telah menjadi sama fungsionalnya dengan arsitektur gedunggedung teater dan gedung-gedung konser baru di mana dia dipertontonkan. ........Dominasi memiliki esterianya sendiri, dan dominasi demikratis memiliki estetika demokratisnya sendiri. Adalah baik bahwa hampir setiap orang sekarang bisa menikmati seni murni, hanya dengan memencet tombol ditempat duduknya, atau hanya dengan masuk kedalam toko obat. Tetapi dalam difusi ini, mereka menjadi gerigi-gerigi dalam suatu mesin-budaya yang mempermak kandungan mereka." ${ }^{31}$

Marcuse di posisi ini melihat bahwa produktivitas peradaban modern, mengontrol masyarakat secara keseluruahan dalam sebuah kekuasaan mesin. Manusia dituntut untuk mengikuti ritme mesin, dan kebebasannya diserahkan pada kekuasaan mesin totaliter. Setelah manusia tunduk dalam pergerakan kekuasaan mesin, dominasi dilanjutkan terhadap masyarakat dengan dibuatnya sebuah kontrol-kontrol baru dalam dunia kebudayaan populer. Melalui bisnis media masa dan hiburan, teknologi menciptakan sistem dominasi yang progresif terhadap bentuk-bentuk kesenangan baru. Kesenangan baru tersebut di ejawanjathakan dalam bentuk manipulasi terhadap kebutuhan esensial manusia. Kebutuhan ini, dimanipulasi sebagai usaha menciptakan kontrol kemajuan pasar dalam menghasilkan pendapatan yang tinggi dan sebagai jaminan kelangsungan dominasi. Marcuse membedakan kebutuhan masyarakat dalam dua bentu, kebutuhan palsu dan kebutuhan yang sebenarnya.

“.......pemikiran-pemikiran individu yang sekarang diserap oleh komunikasi massa dan indoktrinasi, penghapusan "opini publik" bersamasama dengan para penciptanya. ....... Intensitas, kepuasan, dan bahkan karakter dari kebutuhan-kebutuhan manusia, di luar tingkat-tingkat biologis, sejauh ini selalu diprakondisikan., ${ }^{32}$

Kebutuhan palsu lahir dari kontrol-kontrol yang diterapkan dalam kesadaran palsu manusia sebagai bentuk pemuasan kesenangan yang telah diambil alih oleh dominasi prinsip realitas. Kontrol prinsip realitas

\footnotetext{
${ }^{31}$ Ibid, hlm.97-98.

${ }^{32}$ Ibid, hlm. 98.
} 
terhapad prinsip kesenangan tidak hanya terjadi dalam ranah kerja namun berkembang dalam ranah pengetahuan, politik dan budaya populer. Sehingga pergeseran kesadaran masyarakat dalam memenuhi kebutuhanya berakibat pada pemenuhan kesenangan yang mengikuti kontrol-kontrol peradaban populer dan lebih mementingkan kebutuhan palsu dari pada kebutuhan sejatinya dalam memenuhi kesenangan seksual.

“.....kebutuhan "palsu" adalah kebutuhan yang dibebankan pada individu oleh adanya kepentingan sosial khusus dalam represinya; keutuhankebutuhan yang mengabaikan kerja, agresivitas, penderitaan, dan ketidakadilan. ..... hasilnya kemudian adalah sebuah eforia di dalam kebahagian. Kebanyakan dari kebutuhan-kebutuhan-kebutuhan untuk bisa rileks, untuk bersenang-senang, untuk berprilaku dan mengkonsumsi sesuatu sesuai iklan-iklan yang ada, untuk mencintai dan membenci apa yang dicintai dan dibenci oleh orang lain...."33

Kebutuhan-kebutuhan semacam ini mempunyai kandungandan fungsi kemasyarakatan yang ditentukan oleh kekuasaan-kekuasaan eksternal di mana individu tidak mempunyai kontrolnya. Dan seluruh perkembangan dan tingkat kepuasan dari kebutuhan-kebutuhan ini bersifat heterogen. Berlakunya kebutuhan-kebutuhan represif ini merupakan suatu fakta yang terjadi dan diterima dalam ketidakpedualian dan kekalahan terhadap prinsip realitas. Kebutuhan ini terlihat pada keinginan agar mempunyai barang-barang lux (mobil mahal mewah, perabotan rumah lengkap, dan lain semacamnya), yang sesuai dengan aturan-aturan yang ditekankan oleh budaya massa. Dalam peradaban represif kebutuhan sejati telah dihilangkan dan digantikan menjadi kebutuhan palsu yang semu. Kebutuhan yang sejati dalam memenuhi kesenangan dan kebahagiaan yang sebenarnya digantikan dalam bentuk kesenangan yang sementara, yang diciptakan sebagai kontrol peradaban terhadap masyarakat.

Peradaban represif tidak hanya telah membentuk sebuah kontrolkontrol baru terhadap masyarakat melalui kebudayaan masa tetapi telah menutup dunia politis manusia. Tertutupnya dunia politik ditandai dengan

\footnotetext{
${ }^{33}$ Ibid, hlm.7.
} 
bergabungnya sistem ekonomi kedalam sistem negara, yang ikut serta mengontrol manusia dalam sekala universal. Kontrol-kontrol yang totaliter atas ekonomi dan teknik kemudian dilanjutkan melalui manipulasi kebutuhan-kebutuhan oleh manusia-manusia lain yang berkuasa. Organisasi-organisasi teknis, menjadi tanda dari kekuatan politik yang mewujudkan dirinya dalam bentuk penguasaan pada produksi masyarakat.

“.........kekuasaan politik menyatakan dirinya sendiri melalui kekuasaannya terhadap proses mesin dan terhadap organisasi teknis dari suatu peralatan. Pemerintah dari suatu masyarakat yang sudah maju atau maasyarakat yang sedang mengalami kemajuan dapat mempertahankan dan mengamankan dirinya hanya ketika pemerintah itu berhasil dalam menggerakan, mengorganisasi dan mengekploitasi produktivitas teknis,....." ${ }^{34}$

Marcuse menggambarkan proses dominasi manusia atas manusia lain melalui konsep bapak purba.

"Dan manusia yang berhasil mendominasi manusia lain adalah bapa $^{35}$.....peradaban hanya dimulai dalam brother clan, ketika tabu, sekarang dipaksakan sendiri oleh brother clan yang berkuasa, merupakan represi dalam kepentingan umum, mempertahankan kelesatarian kelompok secara keseluruhan. ....... dan peristiwa psikologis yang menentukan yang memisahkan brother clan dari kelompok purba adalah perkembangan rasa bersalah. Kemajuan yang melampui kelompok purba yakni, peradaban mengandaikan adanya rasa bersalah: peradaban mengintroyeksi pada individu dan, dengan demikian, mempertahankan larangan-larangan, kekangan-kekangan,dan penundaan-penundaan pemuasan kebutuhan yang utama yang kepadanya peradaban tergantung. ${ }^{36 "}$

Konsep Bapa purba digambarkan sebagai pusat kekuasaan sebuah kelompok genus (filogenesis). Bapa purba menjadi sumber otoriter kelompok dan membuat sebuah hukum-hukum dan nilai-nilai dalam mengatur

\footnotetext{
${ }^{34} \mathrm{Ibid}, \mathrm{hlm} .4-5$.

${ }^{35}$ Herbert Marcuse, Cinta dan Peradaban, Op Cit, hlm. 76.

${ }^{36} \mathrm{Ibid}, \mathrm{hlm} .79$.
} 
kelangkaan realitas. Dalam pengorganisasian ini, bapak purba menyatukan semua unsur; rasionalitas dan irasionalitas, faktor sosiologis, biologis, kepentingan umum dan khusus, dalam sebuah kontrol terhadap realitas dalam upaya mempertahankan kekuasaannya. Dengan membangaun perkembangan peradaban yang selanjutnya, bapa purba menyiapkan landasan bagi kemajuan melalui pembatasan-pembatasan yang dipaksakan terhadap kesenangan manusia, sehingga kelangsungan kekuasaan bapa purba terpelihara.

Marcuse menggambarkan, pembangunan dominasi yang terus menerus dilakukan oleh bapa purba sebagai alat penegasan terhadap kepentingannya sendiri. Bapa purba menciptakan keteraturan yang membuat semua kelompok, baik ekonomi, sosial, dan masyarakat pekerja dalam sebuah hukum-hukum yang ketat, sehingga bapa purba mampu mengatur masyarakat dalam skala universal dan dalam batas ruang dan waktu. Konsep ini di gambarkan dalam sebuah sistem otoritas yang dilakukan oleh bapa purba pada perdaban sekarang ini.

“....kecendrungan utamanya mudah dikenal: adanya pemusatan ekonomi nasional pada kebutuhan korporasi-korporasi besar, dan pemerintah bertindak sebagai suatu kekuatan yang merangsang, mendukung, dan kadang-kadang bahkan mengontrol, menambatkan ekonomi ini pada sistem alianasi-alianasi militer yang berskala internasional, perjanjianperjanjian moneter, bantuan-bantuan teknis dan rencana-rencana pembangaunan; asimilasi bertahap antara populasi kerah-putih dan pekerja kasar (blue collar), antara tipe-tipe kepemimpinan bisnis dan kerja buruh, ......menguatkan suatu harmoni yang sudah mapan antara kesarjanaan dengan tujuan-tujuan nasional..." ${ }^{\text {37 }}$

Marcuse melihat di dalam dunia politik, kecendrungan dominasi negara mengejawantahkan dirinya dalam bentuk pemikiran satu dimensi sebagai sebuah usaha penyatuan dan pemusatan antara banyak unsur yang berlawanan menjadi sebuah sistem pemikiran yang terkontrol. Penyatuan dari hal-hal yang berlawanan ini menciptakan kemungkinan-kemungkinan adanya perubahan sosial yang mampu mencakup semua strata antara kelas-

\footnotetext{
${ }^{37}$ Herbert Marcuse, Manusia Satu Dimensi, Op Cit, hlm. 28-29.
} 
kelas yang eksistensinya menciptakan oposisi terhadap sistem sebagai keseluruhan yang dapat dikendalikan. Pemikiran-pemikiran manusia yang beraneka ragam disatukan dalam sebuah kaliamat-kalimat kenegaraan dan semboyan-semboyan kekuasaan.

Dimensi politis ditutup oleh kontrol-kontrol yang lebih efisien. Manusia hanya bisa mengikuti kenyamanan dan kesenangan yang ditawarkan oleh peradaban tersebut apabila tidak ingin memilih perang. Dengan kerjasama yang kuat antara kekuasaan politik dengan organisasi teknis, negara mampu menciptakan kontrol dalam sebuah ancaman perang. Kontrol-kontrol baru yang dihasilkan dalam bentuk senjata dan alat-alat pengendali yang lebih canggih lainnya, mengancam kebebasan eksistensi manusia dan eksistensi kemanusian.

“.....produktivitas yang terus berkembang maupun standar kehidupan yang tinggi tidaklah tergantung pada ancaman dari luar, tetapi tergantung pada pemanfaatan dalam hal pencegahan terhadap perubahan sosial dan kelanjutan dari perbudakan. ......sekali lagi; kepercayaan bodoh dari keseluruhannya membebaskan kepercayaan bodoh yang bersifat khusus dan mengubah kejahatan terhadap kemanusiaan menjadi suatu usaha rasional. .....Bahkan kalkulasi paling bodohpun bersifat rasional; pembantaian 5 juta manusia lebih dipilih dari padapada pembantaian 10 juta orang, 20 juta dan seterusnya." ${ }^{38}$

Kehancuran umat manusia, perang dan kemakmuran, dicampurkan oleh negara industri modern. Teknologi modern yang membawa kemakmuran telah menciptakan sebuah kendali terhadap pemberontakan dengan diciptakannya senjata-senjata supermodern yang siap mengancam eksistensi manusia. Kritik dan kebebasan berpikir yang diusungnya hanya sebagai status quo, agar membetulkan serta menaikan kualitas sistem dan dalam upaya kontrol agar tidak keluar dari sistem yang telah ditetapkan.

Kebebasan manusia dalam seluruh aktivitas eksistensinya tunduk dalam sistem pengorganisasian. Melalui sistem persaingan yang ditekankan oleh peradaban modern, pemisahan antara kepentingan individu dalam

\footnotetext{
${ }^{38}$ Ibid, hlm.79.
} 
kategori-kategori kepentingan dominasi semakin dibenarkan. Sehingga kebebasan manusia dengan lahirnya teknologi, kontrol pasar dan kontrol negara semakin menghilangkan eksistensi manusia. Manusia modern adalah manusia tidak sehat. Manusia yang terus menerus memproduksi penindasannya sendiri.

Marcuse pada titik ini, melihat bahwa kemajuan peradaban cenderung membuat rasionalitas ini menjadi rasionalitas palsu. Kebebasan dan pemenuhan kebutuhan yang ada di ikat dengan kuat pada prasyaratprasyarat dominasi, sehingga kebebasan dan pemenuhun kebutuhan itu sendri justru menjadi instrumen represi. Alasan kelangkaan, yang telah mengesahkan represi yang di lembagakan tidak hanya oleh industri kapitalis, tetapi juga oleh negara, telah merubah rasa sakit kedalam bentuk kesenangan-kesenangan palsu yang dirasionalkan. Manusia telah kehilangan kebebasannya dan daya kritisnya telah hilang dan diganti oleh kesadaran palsu akan kesenangan-kesenangan yang ditawarkan oleh peradaban. Dengan di tutupnya dunia politis, pembelokan budaya masa, dan menutupnya semesta wacana, telah melahirkan manusia dalam satu dimensi. Eksistensi manusia dibelokan dan dirubah dalam satu pemikiran yang dikendalikan, sebagai upaya memajukan peradaban industri modern yang represif.

\section{Herbert Marcuse: Pembebasan Sebuah Jalan Buntu}

Marcuse memulai proyek pembebasan manusia dalam peradaban modern yang represif, dengan medasarkan pemikirannya pada sebuah tesis bahwa gerak kemajuan teknologi dan ilmu pengetahuan yang maju di masyarakat industri modern sebagai sebuah prestasi nyata yang tidak boleh diabaikan. Kekuatan pembebas yang ada pada kekuatan produksi harus dihilangkan sifat represifnya sehingga tidak lagi memperbudak manusia. kekuatan-kekuatan pembebasan harus dilepaskan dari fungsinya dalam masyarakat represif sebagai alat-alat produksi, baik yang bersifat material maupun intelektual. Sehingga kekuatan pembebasan tersebut dapat 
dipergunakan sebagai alat pembebasan manusia dari dominasi kerja dan kemiskinan. ${ }^{39}$

Kekuatan-kekuatan pembebasan muncul dalam kesadaran dan kepekaan baru yang hadir berasal dari kelompok masyrakat yang radikal. Munculnya kepekaan serta kesadaran baru tersebut telah menjadi suatu faktor politis yang perlu diperhitungkan oleh teori kritik masyarakat dalam usahanya membentuk masyarakat yang bebas. Kepekaan dan kesadaran akan memperkuat perjuangan melawan ketidakadilan dan kemalangan serta akan membentuk perkembangan selanjutnya dari macam dan tingkat kehidupan. $^{40}$

Naluri kehidupan baru, yang muncul berkat kepekaan dan kesadaran tersebut akan mengatur produksi dan distribusi sesuai dorongan kebebasan. Kesadaran yang telah dibebaskan dari cengkeraman masyarakat yang represif akan mengembangkan ilmu pengetahuan dan teknologi agar memungkinkan kehidupan yang manusiawi. Rasa, Fantasi, Imajinasi dan angan-angan (sensuousness and imagination) yang dalam masyarakat sebelumnya terpenjara dalam terali-terali establisment, kini akan mengatur gerak akal budi (rasio). Teknik akan menjadi seni dan seni akan membentuk kenyataan (reality) baru. Seni yang belum terkontaminasi oleh teknologi dan lebih mempertahankan fantasi sebagai cara berpikirnya merupakan sebuah kekuatan pembebasan dari prinsip realitas yang represif.

“......hanya satu mode berpikir yang selamat dari pengaruh aparatus mental yang baru ini dan tetap bebas dari pengaruh peraturan prinsip realitas: fantasi terlindungi dari perubahan-perubahan kultural dan tetap terikat pada prinsip kesenangan. ${ }^{41}$ Mode ini........, yang dimulai dengan permainan anak-anak, kemudian berlanjut sebagai lamunan, menolak ketergantungan pada objek nyata. ${ }^{42 "}$

${ }^{39}$ Lihat catatan J Sudarminta, Kritik Marcuse Terhadap Masyarakat Industri Modern, dalam Buku Manusia Multi Dimensional, Gramedia, Jakarta, 1982, hlm.142.

${ }^{40} \mathrm{Ibid}$.

${ }^{41}$ Herbert Maruse, Cinta dan Peradaban, Op Cit, hlm.15.

${ }^{42} \mathrm{Ibid}, \mathrm{hlm} .180$. 
Fantasi (imajinasi) mempertahankan kebebasannya terhadap dominasi prinsip realitas dan memainkan fungsi struktur mental yang paling penting dalam keseluruhan struktur mental manusia. Fantasi merupakan sebuah proses berpikir yang menggunakan hukum dan nilai kebenarannya sendiri dan menolak setiap aturan yang ditetapkan dari luar dirinya. Fantasi menggabungkan segala unsur yang tidak mampu dipersatukan oleh prinsip realitas menjadi sebuah perwujudan yang harmoni antara hasrat keinginan dan kenyataan, antara kebahagiaan dan akal budi. Fantasi menempatkan dirinya diluar kekuasaan prinsip realitas dan terus mengancam setiap kemapanan yang dibangaun olehnya. Sehingga terus menerus menutut pengembalian esensi kerja sesuai dengan kebebasan manusia dan mengembalikan arah perkembangan peradaba.

“........fantasi, aktivitas mental yang 'diberikan bebas dari pengujian-realitas dan tetap merupakan satu-satunya aktivitas mental yang berada dibawah pengaruh prinsip kesenangan. Fantasi tidak hanya memainkan peran yang menentukan dalam manifestasi seksualitas yang menyimpang; sebagai imajinasi artistik, fantasi juga menghubungkan penyimpangan ini dengan citra-citra kebebasan dan pemuasan kebutuhan yang integral." ${ }^{\text {33 }}$

Fantasi pada tahap selanjutnya, mendapatkan kebenarannya ketika imajinasi mengambil bentuk dalam menciptakan semesta persepsi dan pemahaman melalui seni. Hubungan dialektis antara seni dan keihudpan sehari-hari dijaga. Sehingga, kreatifitas manusia yang dinegasi dalam prinsip prestasi memperoleh perwujudannya pada karya seni. Dan insting kesenangan manusia yang telah dihilangkan oleh dominasi peradaban represif menadapatkan celah pembebasan melalui seni. Sehingga seni mempresentasikan ketidakbebasan dalam kebebasannya sebagai bentuk sintesis dari pemberontakannya.

"Di bawah pengaruh peraturan prinsip prestasi, seni melawan represi 'citra manusia sebagai subjek yang bebas' yang dilembagakan; namun dalam kondisi tidak bebas seni hanya dapat mempertahankan citra kebebasan dalam penolakannya pada ketidakbebasan. .......agar dapat ditolak, ketidakbebasan ini harus dipresentasikan dalam karya seni dalam bentuk 
yang menyerupai realitas. Elemen kemiripan dengan realitas ini (memperlihatkan, Schein) tidak bisa tidak memaksa realitas yang direpresentasikan tersebut tunduk pada standar-standar estetik...." ${ }^{44}$

Kehidupan sosial ditransendensi oleh kekuatan yang dipunyai oleh seni. Melalui proses dialektis dengan kehidupan sehari-hari manusia, seni akan melahirkan sebuah prinsip realitas yang baru dalam suatu aesthetic ethos yang akan menjadi kerangka masyarakat sendiri. Imajinasi dengan menyatukan akal budi dengan kepekaan indra yang menjadikannya produktif sejauh hal itu menjadi praksis, merupakan arah pedoman pembangunan kembali kenyataan yang sekarang ada. Dengan bantuan gaya scienza (ilmu pengetahuan yang gembira), suatu istilah dalam menyebutkan tekknik dan ilmu pengetahuan yang sudah dibebaskkan dari sifatnya yang memperbudak manusia, kenyataan terrsebut dapat dibangun kembali untuk menjadikan sebuah dunia yang di dalamnya terdapat alam dan dorongan kebebasan manusia yang sesuai.

“...dimensi estetik ini juga merupakan medium yang dengannya alam dan kebebasan dapat bertemu. Kedua sisi mediasi ini sangat dibutuhkan karena adanya konflik luas antara kemampuan manusia yang lebih rendah dan lebih tinggi yang disebabkan oleh kemajuan peradaban upaya filosofis untuk memediasi, dalam dimesi estetik, antara indera dan akal budi, dengan demikian, nampak sebagai upaya mempersatukan dua ranah eksistensi manusia yang dipisahkan menjadi berkeping-keping oleh prinsip realitas yang represif." ${ }^{45}$

Aesthetic ethos merupakan karya yang memiliki kapasitas kritis yang bersifat transendental dalam relasinya pada kehidupan yang menyehari dalam menolak ketidakbebasan. Dengan upaya memediasi antara dua kekuatan yang terpisahkan oleh prinsip realitas, dimensi estetik memperkuat indera untuk melawan tirani akal budi dan menuntut pembebasan indera dari dominasi akal budi yang represif. Disiplin estetik menempatkan aturan inderawi sebagai pengimbang dari aturan akal budi.

\footnotetext{
${ }^{44}$ Ibid, hlm.184.

${ }^{45}$ Ibid, hlm.229.
} 
Sehingga dimensi estetik kembali membangkitkan prinsip kesenangan yang telah dihilangkan menjadi sebuah kekuatan baru dalam membangaun realitas yang bebas.

Marcuse mengatakan bahwa dalam seni estetik terdapat dua karakter. Yakni seni sebagai afirmasi pada kebudayaan yang mapan, yang lebih dimaknai sebagai alat dominasi peradaban represif dan ikut serta memajukan dominasi. Kedua, seni sebagai alienasi dari realitas yang mapan. Dalam pengertian yang kedua seni dilihat sebagai kekuatan yang menegasi setiap realitas yang mapan.

"Di balik bentuk estetik yang disublimasi, isi yang tidak tersublimasi mengemuka: komitmen seni pada prinsip kesenangan. .....kebenaran nonkonseptual indera disakralkan dan kebebasan dari prinsip realitas diberikan pada permainan bebas imajinasi kreatif. ....karena realitas lain yang bebas ini dihuubungkan pada seni dan pengalaman-pengalaman diatributkan pada sikap estetik, realitas ini adalah realitas yang tidak mengikat dan tidak melibatkan eksistensi manusia dalam kehidupan sehari-hari; pendek kata, realitas ini tidak nyata." ${ }^{46}$

Seni yang tersublimasi dalam prinsip realitas selalu membuat sebuah pemberontakan dan menjadi momen di mana prinsip kesenangan selalu menggoyah kemapanan prinsip realitas. Dalam proses dialektis, seni mengambil bentuk dari nilai-nilai yang sedang berlangsung, dan pada sisi lain seni keluar dari sistem tersebut dan mengambil jarak dengan kehidupan sehari-hari sehingga seni mendapatkan posisi dalam menegasi realitas yang melatarbelakanginya. Di posisi inilah, kemudian prinsip kesenangan masuk dan menegasi setiap aturan yang dibangun oleh prinsip realitas. Sehingga melahirkan sebuah realitas baru yang bebas dan tidak mengikat.

Marcuse melihat bahwa seni membentuk perlawanan terhadap prinsip realitas melalui proses permainan. Dalam peradaban yang benarbenar manusiawi, eksistensi manusia adalah bermain, bukan bekerja keras

\footnotetext{
${ }^{46}$ Ibid, hlm. 235 .
} 
dan manusia akan hidup dalam display atau pertunjukan, bukan dalam kebutuhan.

"Manusia mampu mewujudkannya ketika realitas kehilangan keseriusannya dan ketika kebutuhannya menjadi ringan (leicht). Kepandaian yang paling besar dan kebodohan yang paling tragis mempunyai satu kemiripan satu sama lain bahwa keduanya hanya mencari yang nyata: bagaimanapun juga, kebutuhan akan keterkaitan pada yang nyata hanyalah akibat dari kebutuhan. Sebaliknya ketidakacuhan pada realitas dan minat pada pertunjukan (show) (dis-play, Schein), adalah tanda-tanda kebebasan dari kebutuhan dan perluasan kemanusiaan yang sejati." 47

Gagasan ini mengemukakan bahwa kebebasan dari realitas akan terjadi ketika prinsip kesenangan masuk dan mengambil alih setiap hukum yang ditetapkan. Sehingga sebuah realitas yang tidak manusiawi akan kehilangan keseriusannya ketika keinginan-keinginan dan kebutuhankebutuhan dapat dipuaskan tanpa kerja yang teralienasi. Sehingga manusia bebas untuk bermainan dengan kemampuan dan pontesialitasnya tanpa didominasi oleh hukum prinsip prestasi. Manusia adalah dunia display atau pertunjukan (schein), dan aturannya adalah keindahan. Manusia dengan cara kehidupan yang tidak konvensional menentang segala macam keseriusan yang palsu dan munafik dan menolak setiap aturan-aturan yang mengekang setiap bentuk kepuasaan.

"Karena merupakan realisasi dari kebebasan, bermain adalah lebih dari realitas moral dan fisik yang mengekang:' '.... manusia hanya serius dengan apa yang dapat disetujui, yang baik, yang sempurna; tetapi dengan keindahan manusia bermain. Formulasi-formulasi semacam itu hanya akan menjadi 'asketisme' yang tidak bertanggung jawab apabila dunia bermain hanyalah hiasan, kemewahan, atau sekedar liburan di dunia yang represif. Namun demikian, disini fungsi estetik dipandang sebagai suatu prinsip yang mengatur keseluruhan eksistensi manusia, dan ini dapat terjadi apabila fungsi ini berlaku secara universal." ${ }^{48}$

\footnotetext{
${ }^{47} \mathrm{Ibid}, \mathrm{hlm} .239$.

${ }^{48} \mathrm{Ibid}, \mathrm{hlm} .240$.
} 
Dorongan bermain merupakan alat pembebasan prinsip kesenangan dari dominasi prinsip realitas. Dorongan ini tidak bertujuan sebagai alat mem-permainkan sesuatu tetapi mempermainkan realitas yang sudah mapan. Sehingga mampu melampui setiap tekanan dari luar tanpa ada ketakutan akan aturan-aturan yang mendominasi eksistensi manusia. Dengan dorongan permainan, manusia tidak lagi didominasi oleh hukumhukum realitas yang mapan.

Dalam peradaban yang benar-benar manusiawi, eksistensi manusia adalah bermain, bukan bekerja keras dan manusia akan hidup dalam display atau pertunjukan, bukan dalam kebutuhan. ${ }^{49}$ Dalam peradaban yang benar-benar bebas, semua hukum yang diciptakan sendiri oleh individu: 'memberikan kebebasan dengan kebebasan adalah hukum negara estetik. $^{50}$

Masyarakat yang bebas, bagi Marcuse, merupakan bayangan dari dimensi estetis yang didasarkan pada keindahan. Yang mana relasi tiap manusia tak lagi didasarkan pada persaingan dan kekerasan pemerasan, menuntut suatu kepekaan yang telah dibebaskan dari kepuasan yang bersifat represif yang diberikan masyarakat sebelumnya. Kepekaan baru tersebut adalah kepekaan untuk menerima bentuk realitas yang telah lama dibayangkan oleh imajinasi estetis, di mana segala bentuk kerja merupakan sebuah permainan yang menyenangkan.

"Dengan bekerja melalui dorongan-dorongan dasar yaitu dorongan bermain fungsi estetik akan mengharmoniskan perasaan dan kasih sayang dengan gagasan-gagasan akal budi, menggembosi hukum akal budi dari kewajiban-kewajiban moralnya dan mendamaikan dengan kepentingankepentingan indera. ${ }^{51}$

Fungsi estetetik yang menekankan keindahan, akan mengubah aktivitas kerja sebagai alienasi terhadap manusia menjadi sesuatu yang

\footnotetext{
${ }^{49}$ Ibid, hlm.239.

${ }^{50} \mathrm{Ibid}, \mathrm{hlm} .249$.

${ }^{51} \mathrm{Ibid}, \mathrm{hlm} .232$.
} 
menyenangkan dan mampu mengharmoniskan unsur-unsur yang bertentangan dalam prinsip realitas menjadi sebuah keutuhan yang bersesuaian dengan imajinasi, pengolahan budi, dan kepekaan rasa, sebagai manifestasi dari kesempurnaan logis. Alam, dunia objektif, akan dialami, bukan sebagai yang menguasai manusia (seperti dalam peradaban yang mapan), tetapi sebagai objek kontemplasi.

Perubahan dalam pengalaman dasar manusia akan merubah objek pengalaman yang dilaluinya. Manusia dibebaskan dari dominasi dan ekploitasi yang kejam dan diganti dalam bentuk bermain. Pada posisi ini, pengalaman estetik akan menolak produktiitas yang kejam dan yang menjadikan manusia hanya sekedar instrumen kerja. Aktivitas kerjanya tidak lagi menjadi jejak perbudakan yang menakutkan, namun berubah menjadi aktivitas yang display dan manusia bebas menunjukan potensialitaspotensialitas yang dimilikinya.

Marcuse dalam pemikirannya tentang kelas revolusi, melihat bahwa kelas buruh bukan lagi menjadi agents of historical of transformation. Kelas buruh pada peradaban industri yang mapan, tidak lagi mempunyai kesadaran untuk membebaskan diri dari dominasi namun malah ikut berkepentingan mempertahankan intitusional sataus quo. Mereka sudah diintegrasikan dalam sistem yang ada. Sehingga manusia yang berada dalam sistem dominasi tersebut menjadi golongan mayoritas yang pasif dan represif. Prinsip kesenangan yang ada dalam proses mentalnya di rubah menjadi kepuasan-kepuasan yang sementara dan terapkan, sehingga keinginan-keinginan dan minat mereka berubah menjadi konformistis.

Pada posisi lain dalam interpretasi terhadap Hegel Marcuse mulai melihat bahwa kebebasan itu tidak mungkin baik dalam ranah keluarga, masyarakat sipil maupun negara. Negara maupun masyarakat tidak akan dapat mewujudkan bentuk kebebasan yang paling bebas. Tidak peduli serasional apapun negara dan masyarakat itu diorganisir negara atau masyarakat itu tidak akan bisa melepaskan diri dari ketidakbebasan. Kebebasan sejati hanya dapat terjadi dalam ranah gagasan. Kebebasan 
merupakan peristiwa spiritual. Kesempurnaan terletak pada menutupnya lingkaran alienatif. ${ }^{52}$

"Filsafat barat berhenti dengan gagasan yang denganya ia memulai. Pada awal dan akhirnya dalam Aristoteles dan Hegel, mode ada yang paling tinggi, Bentuk puncak akal budi dan kebebasan nampak sebagai nous, ruh, geist. Pada awal dan akhirnya, dunia empiris tetap berada dalam negativitas bahan-bahan dan peralatan jiwa, representasinya di dunia. dalam realitas, ingatan maupun pengetahuan absolut tidak mendapatkan kembali masa lalu dan masa kini. Filsafat ini masih mewartakan tidak hanya prinsp realitas yang mengatur dunia empiris tetapi juga negasi. Di antara awal dan akhir adalah perkembangan akal budi sebagai logika dominasi kemajuan melalui alienasi. Kebebasan yang direpresi dipertahankan: gagasan dan dalam cita-cita. ${ }^{, 53}$

Filsafat Hegel hanya menggantikan gagasan kemajuan dengan gagasan gerakan yang melingkar, mencukupi dirinya sendiri dalam reproduksi dan penyempurnaan diri. Perkembangan ini mengandaikan keseluruhan sejarah manusia (dunia subjektif dan dunia ojektif) dan pemahaman sejarah manusia sendiri ingatan masalalu yang hadir dalam kehidupan ruh dan menentukan kehidupan yang sekarang dan akan datang. Kebebasan mengandaikan rekonsiliasi penembusan masa lalu. Apabila masa lalu dilupakan begitu saja maka tidak akan ada akhir bagi proses transgresi dan destruktif.

Marcuse melihat bahwa hanya filsafat Nietzshe yang mampu melampui tradisi ontologis. ${ }^{54}$ Nietzshe dalam kehendak berkuasanya, menyebutkan bahwa kehendak ini merupakan pembebas dan pembawa kebahagiaan, namun di akhir pemikirannya tersebut Nietzsche mengungkapkan bahwa kehendak itu sendiri tidak bebas. Kehendak tidak bebas karena tidak punya kuasa atas waktu, masa lalu tetap tidak bebas sehingga menggagalkan semua pembebasan. Pada sisi ini, manusia tidak lain merupakan ada yang terbatas dan kematian adalah esensinya.

\footnotetext{
${ }^{52}$ Herbert Marcuse, Eros and Civilization, Op Cit, hlm. 149.

${ }^{53} \mathrm{Ibid}$.

${ }^{54}$ Ibid, hlm.151.
} 
“.....proses-prose primer aparatus mental, dalam perjuangannya mencari pemuasan yang komplet, integral, nampaknya tidak dapat dipisahkan dari perjuangan yang paling universal dari semua substansi yaitu kembali keketenangan, kedamaian dunia anorganik. Insting-insting diseret masuk ke dalam orbit kematian ...... di luar sifat umum kehidupan instingtif, muncullah dua insting yang antagonistik. Insting kehidupan (Eros) mendapatkan kekuasaannya atas insting kematian. ...... kedua insting tersebut memulai fungsi reproduksi kehidupan dengan memishkan sel-sel dari organisme dan menggabungkan kembali sel-sel tersebut. Yang mengarah pada pembentukan dan pelestarian kesatuan yang semakin besar kehidupan. Dengan demikian, kedua insting tersebut mengalahkan, mengangkangi kematian, yaitu kematian potensial yang ada dalam substansi yang hidup." ${ }^{55}$

Dengan kembalinya idea kebebasan pada ranah gagasan dan seni, memperlihatkan bahwa pembebasan itu sendiri hanya mampu terjadi pada tingkat kesadaran manusia yang belum dikendalikan oleh hukum-hukum prinsip realittas. Dan pembebasan tersebut hanya mampu terjadi dari luar, yakni oleh sekelompok kecil masyarakat minoritas yang terbebas dari sistem peradaban yang represif. Kelompok minoritas tersebut digambarkan sebagai sebuah kelompok intelektual yang belum dibekukan oleh sebuah sistem dan oleh para seniman yang masih terus menjunjung tinggi prinsip-prinsip kesenangan dalam mengg-erogoti setiap kemapanan peradaban represif. Sehingga kelompok-kelompok tersebut mampu menghancurkan bangunan sistem dominasi melalui gerakan-gerakan pembebasan dalam membangkitkan kesadaran masyarakat mayoritas terhadap peradaban yang irasionalitas dan tidak sehat.

“.....penyimpangan ini menempatkan dirinya di luar kekuasaan prinsip prestasi dan mengancam dasar prinsip prestasi. .....penyimpanganpenyimpangan ini adalah simbol apa yang harus ditindas agar penindasan tersebut dapat menjadi dominan secara esensial berubah dalam perkembangan peradaban.”

\footnotetext{
${ }^{55}$ Herbert Marcuse, Cinta dan Peradaban, Op Cit, hlm. 30-31.
} 
Pemikiran Herbert Marcuse seputar eksistensi manusia dalam represi peradaban modern di mulai dengan penjabaran tentang asal muasal represi manusia yang menitikberatkan pada proses pengekangan peradaban modern terhadap eksistensi manusia yang akhirnya membentuk manusia menjadi manusia satu dimensi. Berdasarkan penjabaran sebelumnya, dapat ditarik tiga tinjauan kritis terhadap pemikiran Marcuse.

Pertama, penjabaran Marcuse tentang eksistensi manusia adalah dibentuk dalam sebuah dialektika yang menegasikan dirinya dengan realitas objektif. Secara tegas memperlihatkan bahwa pemikirannya yang sangat terpengaruh oleh filsafat idealis Hegel masih bermain dalam ranah gagasan. Ini berbeda jauh dari pemikiran Marx yang lebih menitik beratkan pada sisi praksis dan dari para pemikir Mazhab frankfurt lainnya. Sehingga menjadikan pemikiran-pemikirannya terlihat lebih abstrak dan tidak secara langsung menganalisis permasalahan pengekangan eksistensi manusia secara konkret.

Dalam beberapa penjabaran Marcuse dalam membahas eksistensi manusia bahwa, eksistensi manusia yang sebenarnya ada dalam bentuk "kita". Kemudian di ejawantahkan dalam hubungan kerja melalui produkproduk kerja itu sendiri, dan dalam usaha penyatuan konflik antara subjek dan objek, antara individu dan realitas objektif, hanya bisa dilakukan dalam sebuah kesepakatan-kesepakatan atau hukum sebuah bangsa. Di satu sisi, pemikirannya tersebut malah secara tidak langsung mengesankan bahwa dia seorang yang humanisme dan sangat optimis terhadap kemampuan negara dalam mengatur masyarakat. Namun, dalam penjabaran lain Marcuse malah berpandangan bahwa negara adalah sumber penindasan terhadap eksistensi manusia. Dalam konsep "Bapak Purba", kembalinya alienasi dan tertutupnya semesta politik, Marcuse malah memperlihatkan sebuah kekecewaan dan rasa pesimisme yang tidak terkendalikan. Perubahanperubahan ini menyulitkan pembaca untuk mampu menyimpulkan perkembangan pemikiran Marcuse tentang eksistensi manusia dan menyiratkan optimisme yang selalu dibangun dalam karya Marcuse terkait dengan persoalan kebebasan manusia masih perlu dikaji ulang. 
Kedua, pandangan Marcuse tentang proses pengekangan manusia dimulai dengan menyatukan psikoanalisa Freud ke dalam filsafat ekonomi Marx dengan sebuah penjabaran-penjabaran yang cukup tajam, walau dalam beberapa sisi penjabarannya terlihat sangat abstrak dan terkesan menjauhkan diri dari realitas yang konkret.

Berdasarkan latar belakang pemikiran Marcuse, ia bukan seorang pengkaji serius pemikiran-pemikiran Freud. ${ }^{56}$ Karenanya, cukup membuat kita mampu menyangsikan keakuratan analisisnya. Pemikiran Marcuse yang berlatar belakang filsafat idealis selalu menjaga jarak dengan pengamatanpengamatan empiris dan tidak terlalu tertarik terhadap pemikiran Freud. Ini dibuktikan dengan ketidakterlibatan Marcuse di dalam penelitianpenelitian empiris yang diadakan oleh institut yang sebagian besar di dasarkan atas kajian psikologis.

Dalam beberapa karyanya Marcuse mencoba membedah psikoanalisa Freud dengan cara membaca karya-karya Freud, sehingga pemikirannya terlihat sangat teoritis dan jauh dari contoh-contoh yang konkret. Namun pada posisi lain, Paul Robinson berpendapat bahwa Marcuse berhasil membuat sebuah khayalan yang cerdas dalam pemikirannya tentang psikoanalisa Freud sehingga mampu membuat penjabaran-penjabaran yang tajam dalam menganalisa proses biologis pengekangan manusia. Ini terlihat dalam analisisnya terhadap prinsip kesenangan dan prinsip realitas yang sangat kompherensif terhadap usaha pembongkaran dasar-dasar penindasan manusia modern.

Ketiga, aspek pembebasan yang ditawarkan oleh Marcuse terjadi dalam beberapa tahap, sesuai dengan pengaruh yang melatarbelakangi pemikirannya. Dalam beberapa aspek Marcuse terlihat sebagai seorang pemikir yang utopis, namun pada sisi lain pemikirannya tentang pembebasan manusia telah memberikan sumbangan yang cukup berarti terhadap arus pemikiran kontemporer.

Dalam usaha pembebasannya, Marcuse sangat berharap kepada segi fantasi yang masih menjunjung tinggi prinsip kesenangan. Marcuse melihat

${ }^{56}$ Tinjauan kritis seputar ketidatertarikan Marcuse terhadap pemikiran Freud dapat dilacak dalam Martin Jay, Loc Cit, hlm.185. 
bahwa fantasi dengan ciri keindahan dan ciri "bermain"-nya mampu menggoyah kemapanan sistem dominasi peradaban modern. Walau pemikiran Marcuse terlihat sangat utopis, tapi analisisnya cukup sangat masuk akal dan dapat diterima, mengingat fungsi seni-seni luhur sampai saat ini masih diakui sebagai negasi dari setiap kemapanan realitas yang melingkupinya. Pada batasan tertentu, ketika mimpi Marcuse untuk membuat sebuah dunia manusia sebagai dunia bermain masih sangat utopis untuk diwujudkan karena peradaban yang sangat rapat menutup celah-celah tersebut untuk digoyah. Marcuse kemudian menitik-beratkan harapan pembebasan manusia kepada intelektual yang belum terkontaminasi sistem yang ada. Namun, pertanyaan seputar masih adakah kelompok sehat yang terjauh dari belenggu sistem penindasan pada saat ini, kembali membenturkan analisisnya menjadi sebuah utopi yang baru.

Pada titik ini, diakui bahwa Herbert Marcuse dengan gaya berberfikirnya yang selalu mempertahanan penjabaran-penjabaran umum dan abstrak terlihat sangat menjunjung tinggi abstraksi, sehingga terlihat seperti seorang pemikir yang melihat dunia di atas menara gading. Di posisi lain, cara penulisan Marcuse yang terlihat cukup otoriter tanpa penjelasan yang sistematis dalam menyuguhkan pemikiran-pemikirannya, sangat bertolak belakang dengan kritik-kritiknya yang mengecam sistem peradaban modern yang dinilai otoriter. Namun dengan ketajaman analisisnya dalam melihat dasar-dasar pengekangan manusia sebagai dasar melihat fenomena peradaban modern, telah memberikan kontribusi yang sangat berarti dalam ranah pemikiran kontemporer.

\section{Simpulan}

Studi kritis terhadap pemikiran Herbert Marcuse, menghasilkan tiga kesimpulan utama yang koheren dengan tiga tujuan penelitian yang telah digariskan di awal penelitian.

Pertama, dalam pemikiran Herbert Marcuse peradaban modern merupakan sebuah peradaban yang tidak sehat dan peradaban modern dengan kemajuan teknologi yang dimilikinya telah menjalankan sebuah bentuk kontrol-kontrol baru terhadap eksistensi manusia. 
Kedua, eksistensi manusia dalam peradaban modern telah dihilangkan dan dirubah menjadi instrumen-instrumen kerja yang represif, sebagai upaya mempertahankan sistem peradaban industri modern. Herbert Marcuse melihat bahwa dengan bersatunya teknologi, sistem pasar, dan negara, telah melahirkan sebuah pengendalian-pengendalian baru terhadap eksistensi manusia yang semakin rasional dan menyenangkan.

Ketiga, dalam pemikiranya yang mencoba mensintesiskan psikoanalisa dengan teori sosial, Herbert Marcuse berhasil membedah struktur penindasan manusia walau dalam berbagai kritik dan kelemahan dalam penjabaran pemikiran-pemikirannya. Sehingga bentuk-bentuk penindasan yang semakin dibenarkkan pada zaman sekarang mendapatkan pembenarannya.[] 


\section{DAFTAR PUSTAKA}

Adelbert Snijders. (2004). Antropologi Filsafat: Manusia, Paradoks dan Seruan. Kanisius: Yogyakarta.

Ali Mudhofir. (2001). Kamus Filsuf Barat. Pustaka Pelajar: Yogyakarta.

Anton Bakker \& Achmad Charris Zubair. (2002). Metode Penelitian Filsafat. Kanisius: Yogyakarta.

Bambang I. Sugiharto. (1996). Postmodernisme: Tantangan bagi Filsafat. Kanisius: Yogyakarta.

Dominic Strinati. (2003). POPULER CULTURE Pengantar Menuju Teori Budaya Populer. Bentang: Yogyakarta.

Erich Form. (1995). Masyaraat yang sehat. Yayasan Obor: Jakarta.

F Budi Hardiman. (2004). Filsafat Modern Dari Machiavelli sampai Nietzsche, Gramedia: Jakarta.

(2007). Fisafat Pragmentaris. Kanisius: Yogyakarta.

(2003). Heideger dan Mistik Keseharian 'Suatu Pengantar Menuju Sein Und Zeit'. Gramedia: Jakarta (2005). Memahami Negativitas. Kompas: Jakarta.

(2009). Kritik Ideologi. Kanisius: Yogyakarta.

Frans Magnis-Suseno. (2005). Pijar-Pijar Filsafat. Kanisius: Yogyakarta.

Fuad Hasan. (1992). Berkenalan Dengan Eksistensialisme. Pustaka Jaya: Jakarta.

Herbert Marcuse. (2000). Manusia Satu Dimensi. Terj. Silvester G. Syukur dan Yusup Priyasudiarja. Yayasan Bentang Budaya: Yogyakarta.

K. Bertens. (1996). Filsafat Barat Kontemporer Prancis. Gramedia: Jakarta. (1996). Filsafat Barat Kontemporer Jerman. Gramedia: Jakarta.

Linda Smith dan William Raeper. (2000). IDE-IDE: Filsafat dan Agama, Dulu dan Sekarang. Kanisius: Yogyakarta.

Martin Jay. (2005). Sejarah Mazhab Frankfurt. Terj. Nurhadi. Kreasi Wacana: Yogyakarta.

M. Sastrapratedja. (1982). Manusia Multi Dimensional. Gramedia: Jakarta.

St. Sunardi. (1996). Nietzsche. LkiS Pelangi Aksara: Yogyakarta.

Tim Penyusun Kamus Pusat Bahasa. (2008). Kamus Bahasa Indonesia. Pusat Bahasa Departemen Pendidikan Nasional: Jakarta.

Yasrap Amir Pilialang. (2003). Hipersemiotika 'Tafsir Cultural Studies Atas Matinya Makna'. Jalasutra: Yogyakarta. 
Yus Badudu. (2003). kamus;kata-kata serapan asing dalam bahasa Indonesia. Penerbit Kompas: Jakarta.

Zainal Abidin. (2000). Filsafat Manusia. Rosda Karya: Bandung.

\section{Sumber lain :}

Budiono Kusumohamidjojo. (26 September 2010). Dialog Kebudayaan Menuju Ko-eksistensi Damai Peradaban. Makalah untuk presentasi pada Extension Course Filsafat (ECF) "Evolusi Peradaban". Fakultas Filsafat Universitas Parahiyangan: Bandung.

F Budi Hardiman. (13 Juni 2009). Humanisme dan Para Kritikusnya. Makalah dalam rangkaian Kuliah Umum "Memikirkan Ulang Humanisme”. Komunitas Salihara: Jakarta.

Goenawan Muhammad. (26 September 2010). Peradaban dan LawanLawannya. Makalah untuk presentasi pada Extension Course Filsafat (ECF) "Evolusi Peradaban". Fakultas Filsafat Universitas Parahiyangan: Bandung.

Justin Pa'at. (12:46, 09/06/2011). Kebudayaan yang Menindas (Pandangan Herbert Marcuse tentang Budaya). http://ryandgr.blogspot.com /2010/11/filsafat.html 